\title{
An Automated Biochemical Assay for Haptoglobin: Prevention of Interference from Albumin
}

\author{
P. D. Eckersall ${ }^{1}$, S. Duthie ${ }^{1}$, S. Safi ${ }^{1}$, D. Moffatt ${ }^{1}$, N. U. Horadagoda ${ }^{1}$, S. Doyle $^{5}$, R. Parton $^{4}$, \\ D. Bennett ${ }^{2}$ and J. L. Fitzpatrick ${ }^{3}$ \\ ${ }^{1}$ Clinical Biochemistry Section, ${ }^{2}$ Division of Small Animal Clinical Studies, ${ }^{3}$ Division of Farm Animal Clinical Studies and \\ Animal Production, Department of Veterinary Clinical Studies, University of Glasgow Veterinary School, Glasgow, UK; \\ ${ }^{4}$ Division of Infection and Immunity, Institute of Biomedical and Life Sciences, University of Glasgow, Glasgow, UK; \\ ${ }^{5}$ Department of Biology, National University of Ireland, Maynooth, Co. Kildare, Ireland
}

\begin{abstract}
Measurement of the acute phase serum protein, haptoglobin $(\mathrm{Hp})$, is performed by biochemical methods based on haemoglobin binding, in many veterinary diagnostic laboratories. During attempts to develop a robust biochemical assay for serum Hp it was discovered that serum albumin interfered with the assay system increasing results by as much as $0.28 \mathrm{mg} / \mathrm{ml}$, which could affect interpretation of results especially in species with low normal Hp concentrations. A reagent cocktail (SB-7) was devised which inhibited the interfering effect of albumin. An automated assay for Hp utilising SB-7 was developed for production as a biochemical assay kit and was evaluated for use in veterinary diagnosis. The intra-assay coefficients of variation were of $0.9 \%, 0.9 \%$ and $1.3 \%$ for $\mathrm{Hp}$ concentrations of $2.0,1.0$ and $0.23 \mathrm{mg} / \mathrm{ml}$, respectively and interassay coefficients of variation of $1.7 \%$ and $4.5 \%$ for $\mathrm{Hp}$ of $2.08 \mathrm{mg} / \mathrm{ml}$ and $0.24 \mathrm{mg} / \mathrm{ml}$, respectively. The lower limit of detection of was $0.02 \mathrm{mg} / \mathrm{ml}$, linearity extended to $8 \mathrm{mg} / \mathrm{ml}$ and recovery was $101 \pm 7 \%$ (mean \pm $\mathrm{SD})$. The assay had correlation coefficients $\left(\mathrm{R}^{2}\right)$ of 0.96 and 0.90 when compared with immunodiffusion assays of canine $\mathrm{Hp}$ and bovine $\mathrm{Hp}$, respectively. Lipaemia and bilirubinaemia caused no interference. Haemolysis did not affect measurement of low levels of $\mathrm{Hp}$, but at serum $\mathrm{Hp}$ concentrations of 0.4 and $1.8 \mathrm{mg} / \mathrm{ml}$ the apparent $\mathrm{Hp}$ concentration was decreased. Elevated concentrations of Hp were measured in cattle with mastitis, dogs with
\end{abstract}

Correspondence and offprint requests to: P. D. Eckersall, Clinical Biochemistry Section, Department of Veterinary Medicine, University of Glasgow Veterinary School, Bearsden Road, Glasgow G61 1QH, UK polyarthritis and rats experimentally infected with Bordetella pertussis. The automated assay is precise and has negligible interference from albumin.

Keywords: Assay; Cattle; Dog; Haemoglobin binding; Haptoglobin; Rat

\section{Introduction}

Haptoglobin ( $\mathrm{Hp})$ is one of the acute-phase proteins in the blood of humans and animals and its concentration varies according to the health status (Whicher and Westacott 1992; Kushner \& Mackiewicz, 1987). Levels increase dramatically during infection, inflammation or trauma and measurement of the concentration of $\mathrm{Hp}$ in serum provides valuable diagnostic information to clinicians in both human (Whicher and Westacott, 1992) and veterinary medicine (Eurell et al. 1992, Skinner \& Roberts 1994). In veterinary medicine, measurement of $\mathrm{Hp}$ is particularly important in assessing the health status of cattle and sheep as, in these species where normal $\mathrm{Hp}$ is $<0.01 \mathrm{mg} / \mathrm{ml}$, there is a particularly strong $\mathrm{Hp}$ response to infection, with the concentration in the circulation increasing up to 100 -fold or more. In other species, such as humans, dogs, cats and pigs more modest increases (2- to 5-fold) occur, but these are still sufficient to provide valuable diagnostic information (Eckersall 1995, Eckersall and Conner 1998).

Hp in human serum can be measured using antibodies specific for human $\mathrm{Hp}$ with methods such as immuno- 
turbidimetry, but for use in veterinary diagnostic laboratories, tests based on antiserum to one species have to be validated for each use in alternative species (Lipperheide et al. 1998; Solter, et al. 1991) and the validation should be repeated for each new batch of antiserum.

Alternative assays for $\mathrm{Hp}$, which can be used for all species, are based on the ability of $\mathrm{Hp}$ to bind to haemoglobin (Hb) (Makimura and Suzuki 1982; Skinner et al. 1991). The original assays depended on the formation of the a $\mathrm{Hp}-\mathrm{Hb}$ complex that alters the absorbance characteristic of $\mathrm{Hb}$ in proportion to the concentration of $\mathrm{Hp}$ in a serum sample (Harvey 1986). More recent methods make use of the innate peroxidase activity of the $\mathrm{Hb}-\mathrm{Hp}$ complex, which can be detected and quantified at a mildly acidic $\mathrm{pH}$ (Makimura and Suzuki 1982). Such assays are used in veterinary diagnostic laboratories and are preferred to immunoassays as they are more convenient and can be performed on all species. However, the automated version of this test (Skinner and Roberts 1994) utilises a reagent, guaiacol, which has a noxious odour and is not accepted by staff in many laboratories. The assay has not been adapted by commercial reagent suppliers. Attempts have been made to use other substrates for the peroxidase reaction and, although this can be achieved for manual methods using tetramethylbenzidine (TMB) (Eckersall et al. 1988) a successful automated assay for Hp, using stable and convenient reagents, is still not widely available.

During studies to develop an automated haptoglobin method a variety of chromogen and buffer mixes were assessed but it became apparent that serum albumin had a significant effect on the peroxidase reaction causing falsely elevated results especially evident in species such as cattle where the normal serum Hp is low. Studies to eliminate the effect led to the development of a novel reagent (called SB-7) for Hp assay which minimised the interference of serum albumin. Here the effect of albumin on automated assays for $\mathrm{Hp}$ is demonstrated by contrasting an assay using the new SB-7 reagent with an automated assay using conventional peroxidase chromogens where serum albumin leads to erroneous levels of $\mathrm{Hp}$. Validation studies on the assay for $\mathrm{Hp}$, with the reagent SB-7 were then performed.

\section{Materials and Methods}

\section{Haptoglobin Assays}

Reagents. Stock solutions were prepared of haemoglobin $(\mathrm{Hb})$ at $30 \mathrm{mg} / \mathrm{ml}$ in $9 \mathrm{mg} / \mathrm{ml} \mathrm{NaCl}$ according to Makimura and Suzuki (1982). A working solution was prepared by diluting the stock solution 1 in 500 in $9 \mathrm{mg} /$ $\mathrm{ml} \mathrm{NaCl}$. Substrate was prepared by addition of $100 \mu \mathrm{l}$ of $30 \%$ hydrogen peroxide $\left(\mathrm{H}_{2} \mathrm{O}_{2}\right)$ to $25 \mathrm{ml}$ of distilled water.

Hp calibrators were prepared by dilution of a bovine acute phase serum in which the haptoglobin concentra- tion had been measured with the manual $\mathrm{Hp}-\mathrm{Hb}$ binding method (Makimura and Susuki 1982; Eckersall et al. 1988) using purified Hp as calibrator (Horadagoda et al, 1994). The standards were diluted as appropriate in 9 $\mathrm{mg} / \mathrm{ml} \mathrm{NaCl}$ or a $2 \%$ bovine serum albumin (BSA, Sigma Chemical Co. Ltd, Poole, Dorset, UK) solution in $9 \mathrm{mg} / \mathrm{ml} \mathrm{NaCl}$ to give concentrations of $2.05,1.025,0.5$ and $0.13 \mathrm{mg} / \mathrm{ml}$.

The new assay for Hp uses a chromogen reagent, SB-7 which is patented and propriety (International Patent Application no. PCT/GB98/03407) and was used as in the manufacturer's instructions for the Phase Haptoglobin Assay kit (Tridelta Development Ltd, Co. Wicklow, Ireland). The reagent is a solution of peroxidase chromogen, detergent and protein binding inhibitors in a citrate buffer at $\mathrm{pH} 3.8$.

Automated Haptoglobin Assay. Standards and serum or plasma samples were dispensed into sample tubes and placed on a biochemical analyser (MIRA analyser, Roche Diagnostics Ltd, Welwyn Garden City, UK). The analyser was programmed so that either a $2.5 \mu \mathrm{l}$ or $7.5 \mu \mathrm{l}$ aliquot of sample or standard was mixed with 200 $\mu \mathrm{l}$ of the diluted haemoglobin. After $50 \mathrm{~s}, 90 \mu \mathrm{l}$ of chromogen solution was added, and $25 \mathrm{~s}$ later, $50 \mu \mathrm{l}$ of substrate, $\left(\mathrm{H}_{2} \mathrm{O}_{2}\right)$ was added. The increase in absorbance with time at $600 \mathrm{~nm}$ for reagent SB-7 and for TMB was monitored. The increase in absorbance at $600 \mathrm{~nm}$ over the $50 \mathrm{~s}$ after substrate addition was used to calculate the standard curve using the analyser's on-board computer program. Hp concentration in unknown samples was derived by comparison with the standard curve. The reaction was maintained at $37^{\circ} \mathrm{C}$ throughout.

Demonstration of the Albumin Effect. To illustrate the effect of albumin on Hp assays in the absence of reagent SB-7 the same methodology, MIRA settings, standards and controls were used with conventional peroxidase chromogens and buffers. The chromogen TMB (Sigma) was prepared for comparison by dissolving at $0.1 \mathrm{mg} / \mathrm{ml}$ in $\mathrm{pH} 3.8$ phosphate buffer (Eckersall et al. 1988). The bovine acute phase serum with haptoglobin at $2.05 \mathrm{mg} /$ $\mathrm{ml}$ was diluted in $9 \mathrm{mg} / \mathrm{ml} \mathrm{NaCl}$ to give standard samples with $\mathrm{Hp}$ at $1.025,0.51$ and $0.13 \mathrm{mg} / \mathrm{ml}$. Zero control samples were $9 \mathrm{mg} / \mathrm{ml} \mathrm{NaCl}$ and $2 \% \mathrm{BSA}$ or $5 \%$ BSA in $9 \mathrm{mg} / \mathrm{ml} \mathrm{NaCl}$. To demonstrate the albumin effect a volume of $7.5 \mu \mathrm{l}$ of sample was used.

The same standards and control samples were analysed with a $\mathrm{Hp}$ assay using $2.2^{\prime}$-azino-bis [ethylbenzothiazoline-6-sulphonic acid] diammonium salt (ABTS) as chromogen with the method of Schmitt et al. (1987) modified to be performed on the MIRA analyser.

Calibration of the Optimised SB-7 Hp Assay. The Hp assay was performed on the MIRA analyser according to the method described above with standards composed of dilutions of acute phase bovine serum in $2 \%$ BSA, with 
the $\mathrm{Hp}$ at concentrations of $2.05,1.025,0.51,0.13$ and 0 $\mathrm{mg} / \mathrm{ml}$. For calibration, validation and subsequent assays a sample value of $2.5 \mu \mathrm{l}$ was used.

Validation of the Hp Assay with SB-7 Reagent. To determine the accuracy of the test, purified human Hp (Sigma) was added to foetal calf serum (FCS) at calculated concentrations of $1.6,1.2,0.8$ and $0.4 \mathrm{mg} /$ $\mathrm{ml}$, assayed for $\mathrm{Hp}$ and the recovery percentage calculated. The specificity of the assay was determined by a parallel dilution study in which four canine serum samples with a high concentration of $\operatorname{Hp}(1.8,1.9,1.45$ and $1.09 \mathrm{mg} / \mathrm{ml}$, respectively) were serially diluted (1 in 2) in a $2 \%$ BSA solution in $9 \mathrm{mg} / \mathrm{ml} \mathrm{NaCl}$ and the change in absorbance at $600 \mathrm{~nm}\left(\Delta A_{600}\right)$ of each dilution plotted beside the standard curve to assess parallelism between dilution and standard curves. To determine the linearity of the assay, four canine serum samples with Hp concentrations above the upper standard of the standard curve $(22.5,14.6,14.5$ and $8.72 \mathrm{mg} / \mathrm{ml})$, were serially diluted and assayed for $\mathrm{Hp}$ with the $\Delta A_{600}$ plotted against concentration calculated by extrapolation.

The precision of the assay was assessed by calculation of the intra-assay and interassay coefficients of variance $(\mathrm{CV})$. The former was determined by ten repetitive assays of three control samples in a single assay run, whereas the interassay $\mathrm{CV}$ was determined by inclusion of two control samples in twelve separate runs carried out on different days.

The limit of detection of the assay was determined as the lowest concentration of $\mathrm{Hp}$ which could be distinguished from a zero sample and was determined by assessment of the concentration of $\mathrm{Hp}$ equivalent to two standard deviations from the mean in the change in absorbance of the zero standard (2\% BSA) in repeated assays $(n=11)$.

The assay was assessed for interference by haemolysis, lipaemia and bilirubinaemia. Canine $\mathrm{Hb}$ at $10 \mathrm{~g} / \mathrm{dl}$ was prepared by addition of distilled water to packed red cells followed by centrifugation to remove cell debris. Dilutions of $\mathrm{Hb}$ at 50,25 and $12.5 \mathrm{mg} / \mathrm{ml}$ were prepared. A $5 \mu \mathrm{l}$ aliquot of each dilution (and distilled water as a zero control) was added to $45 \mu \mathrm{l}$ of canine sera with $\mathrm{Hp}$ concentrations of 2.02 and 0.45 and to a bovine serum with $0.02 \mathrm{mg} / \mathrm{ml}$ of $\mathrm{Hp}$. The samples, which had final $\mathrm{Hb}$ concentrations of $1.25,2.5,5.0$ and $10 \mathrm{mg} / \mathrm{ml}$, were assayed for $\mathrm{Hp}$ in triplicate. Similarly the effect of lipaemia was assessed by assaying for $\mathrm{Hp}$ in the sera which contained intralipid (KabiVitrum Ltd, Uxbridge, UK) over a range from $0.1 \%$ to $1 \%(\mathrm{v} / \mathrm{v})$. The sera had Hp concentrations of 0.63 and $1.50 \mathrm{mg} / \mathrm{ml}$ in the absence of lipid. The effect of bilirubinaemia was assessed by adding bilirubin over the range 5.9-95 $\mu \mathrm{mol} / \mathrm{l}$ to sera with $\mathrm{Hp}$ concentrations of 0.44 and $2.03 \mathrm{mg} / \mathrm{ml}$.

The effect of anticoagulants on the assay was determined by analysis of serum and plasma taken at the same time from the same animal. An initial study showed that the use of EDTA as an anticoagulant had no effect on the assay for $\mathrm{Hp}$, with identical results being obtained to those in serum. However, plasma prepared using heparin as anticoagulant showed a slight increase in the apparent $\mathrm{Hp}$ concentration. This was examined further by preparation of plasma with heparin at $10 \mathrm{IU} /$ $\mathrm{ml}, 20 \mathrm{IU} / \mathrm{ml}$ and $40 \mathrm{IU} / \mathrm{ml}$. Heparin is usually included in sample tubes to give a final concentration of $10 \mathrm{IU} / \mathrm{ml}$.

\section{Comparison with Immunodiffusion}

To assess the relation of the present assay to alternative systems, 40 bovine serum samples and 40 canine plasma (heparin) samples assayed in the SB-7 Hp assay were also assayed for $\mathrm{Hp}$ using species-specific radial immunodiffusion kits (Saikin Kagaku, Sendai, Japan) according to the manufacturer's instructions.

\section{Applications of the SB-7 Hp Assay}

The assay was used to measure Hp concentration in serum or plasma from clinical cases in cattle and dogs, and in plasma from experimental rats.

Cattle. Sera from 18 cases of bovine mastitis and from 23 healthy cows in the same dairy herds were assayed for their Hp concentration.

Dogs. The Hp concentration was determined in plasma (heparin) collected for diagnostic biochemical analysis from eight dogs of mixed breed with polyarthritis, and in serum collected from 27 mixed breed dogs as part of a health assessment. The latter group only contained dogs without clinical or other sign of disease.

Rats. Serum samples were obtained from eight rats at 8 and 28 days after intrabronchial infection with Bordetella pertussis (Hall et al. 1994) and from eight control, uninfected rats.

\section{Statistics}

Descriptive statistics, correlations, regression equations and the difference between groups by Student's $t$ test were calculated using the Minitab statistical package (version 12.0). Differences were regarded as significant at $p<0.05$.

\section{Results}

\section{Demonstration of the Albumin Effect}

At $\mathrm{pH}$ 3.8, as used in the Hp assay, the oxidised TMB chromogenic product was not stable, with a visible change from the initial blue chromogenic product to a green and finally a yellow product. However, after a 1:10 dilution of all standards, controls and samples an automated assay was possible but in these conditions the $\mathrm{Hp}$ assay of the control samples with $2 \%$ and $5 \%$ 
Table 1. Effect of albumin on Hp assays with various chromogens on the apparent haptoglobin content of samples using saline as a zero control

\begin{tabular}{lll}
\hline Chromogen & \multicolumn{2}{l}{ Apparent $\mathrm{Hp}(\mathrm{mg} / \mathrm{ml})$} \\
\cline { 2 - 3 } & $2 \%$ BSA & $5 \%$ BSA \\
\hline TMB & 0.10 & 0.16 \\
ABTS & 0.10 & 0.28 \\
SB-7 & 0.009 & 0.02 \\
\hline
\end{tabular}

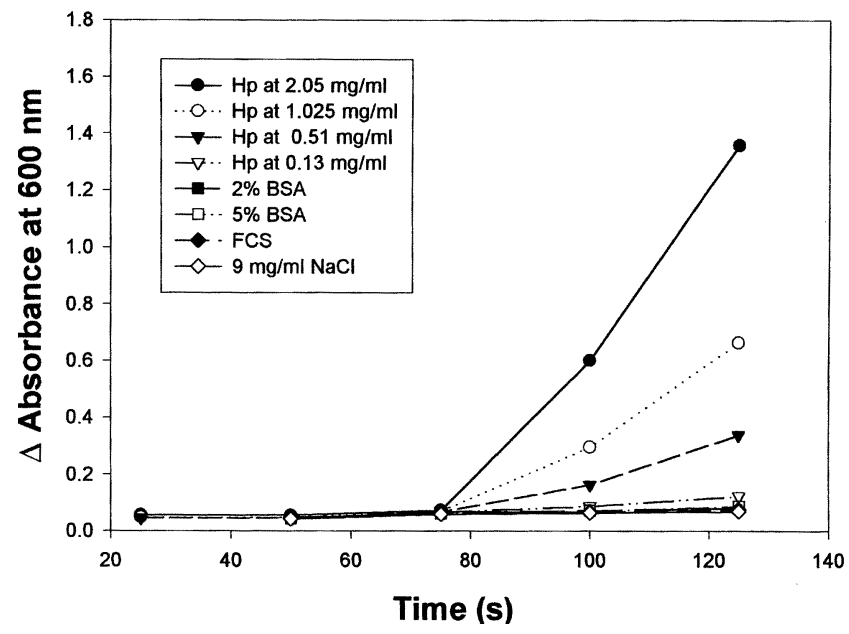

Fig. 1. The increase in absorbance at $600 \mathrm{~nm}$ in assays for Hp using reagent SB-7 with samples containing $\mathrm{Hp}$ at $2.05 \mathrm{mg} / \mathrm{ml}(\boldsymbol{O}), 1.025$ $\mathrm{mg} / \mathrm{ml}(\bigcirc), 0.51 \mathrm{mg} / \mathrm{ml}(\boldsymbol{\nabla})$ and $0.13 \mathrm{mg} / \mathrm{ml}(\nabla)$ in $9 \mathrm{mg} / \mathrm{ml} \mathrm{NaCl}$ and $2 \%$ BSA $(\square), 5 \%$ BSA $(\square)$, fetal calf serum $(\bullet)$ and $9 \mathrm{mg} / \mathrm{ml}$ $\mathrm{NaCl}(\diamond)$ as controls.

albumin caused an increase in $A_{600}$ which led to apparent haptoglobin in the samples of up to $0.16 \mathrm{mg} / \mathrm{ml}$ (Table 1). When ABTS was used as the chromogen the apparent $\mathrm{Hp}$ concentration rose to $0.28 \mathrm{mg} / \mathrm{ml}$ in the $5 \%$ BSA sample (Table 1). The assay with SB-7 as the chromogen showed an apparent $\mathrm{Hp}$ content of $0.02 \mathrm{mg} / \mathrm{ml}$ with $5 \%$ BSA and only $0.009 \mathrm{mg} / \mathrm{ml}$ with $2 \%$ BSA. To minimise the residual interference from albumin in serum samples, $2 \%$ BSA was used for dilution of standards and was included as zero sample in all other assays for Hp. The $\Delta A_{600}$ of standards and controls with the SB-7 assay reagent (Fig. 1) illustrates the minimal effect of albumin and FCS on this chromogen.

\section{Calibration of the Optimised SB-7 Hp Assay}

A consistent linear relationship was found between the $\Delta A_{600}$ and the concentration of $\mathrm{Hp}$ when the mean $\Delta A_{600}$ for five standard curves was plotted against the $\mathrm{Hp}$ concentration (Fig. 2). The standard curve was linear with a regression equation of $y=0.035+0.22 x$ and correlation coefficient $\left(R^{2}\right)$ of 0.999 with the standard deviation of estimate being 0.008 , the slope $( \pm$ SD) was $0.22 \pm 0.002$ and the intercept $( \pm \mathrm{SD})$ was $0.035 \pm 0.002$.

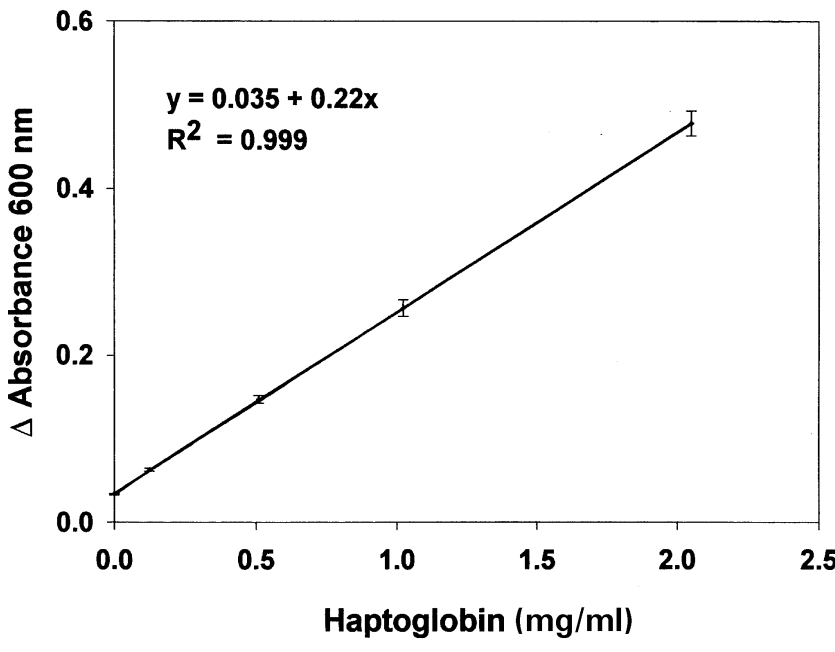

Fig. 2. The increase in absorbance at $600 \mathrm{~nm}$ in the Hp assay with reagent SB-7 in response to increasing concentrations of serum $\mathrm{Hp}$ in calibration standards, each point is the mean \pm SD of five standard curves.

Validation of the SB-7 Reagent in the Hp Assay

The accuracy of the assay calculated as the recovery of added human Hp varied between (mean \pm SD) and $108 \pm$ $7.02 \%$ with a mean of $101 \pm 7.38 \%$ (Table 2 ) and the dilution curves of canine serum were parallel to the standard curve (Fig. 3a). Examination of dilutions of canine serum samples which had considerably greater concentrations of $\mathrm{Hp}$ than the top standard showed that there was a linear relation between the change in absorbance and $\mathrm{Hp}$ concentration up to $8 \mathrm{mg} / \mathrm{ml}$. (Fig. $3 b)$.

The precision of the assay is given in Table 3 and shows that the intra-assay CV was between $0.88 \%$ and $1.3 \%$, whereas the interassay CV was between $1.68 \%$ and $4.5 \%$. The limit of detection of the $\mathrm{Hp}$ assay was determined as being $0.02 \mathrm{mg} / \mathrm{ml}$ which was the concentration of $\mathrm{Hp}$ at a change in absorbance two standard deviations above the mean change in absorbance reading of replicate $(n=11)$ assays of the zero standard.

Table 2. Accuracy of haptoglobin assay with SB-7 reagent; recovery of human haptoglobin added to fetal calf serum

\begin{tabular}{lllll}
\hline $\begin{array}{l}\text { Hp added } \\
(\mathrm{mg} / \mathrm{ml}) \\
(n=5)\end{array}$ & $\begin{array}{l}\mathrm{Hp} \\
\text { recovered } \\
(\mathrm{mg} / \mathrm{ml})\end{array}$ & $\mathrm{SD}$ & $\begin{array}{l}\% \\
\text { recovery }\end{array}$ & $\mathrm{SD}$ \\
\hline 1.6 & 1.74 & 0.11 & 108 & 7.02 \\
1.2 & 1.23 & 0.04 & 103 & 3.54 \\
0.8 & 0.80 & 0.03 & 100 & 3.14 \\
0.4 & 0.37 & 0.02 & 93 & 5.42 \\
& & mean recovery $=$ & 101 & 7.38 \\
\hline
\end{tabular}



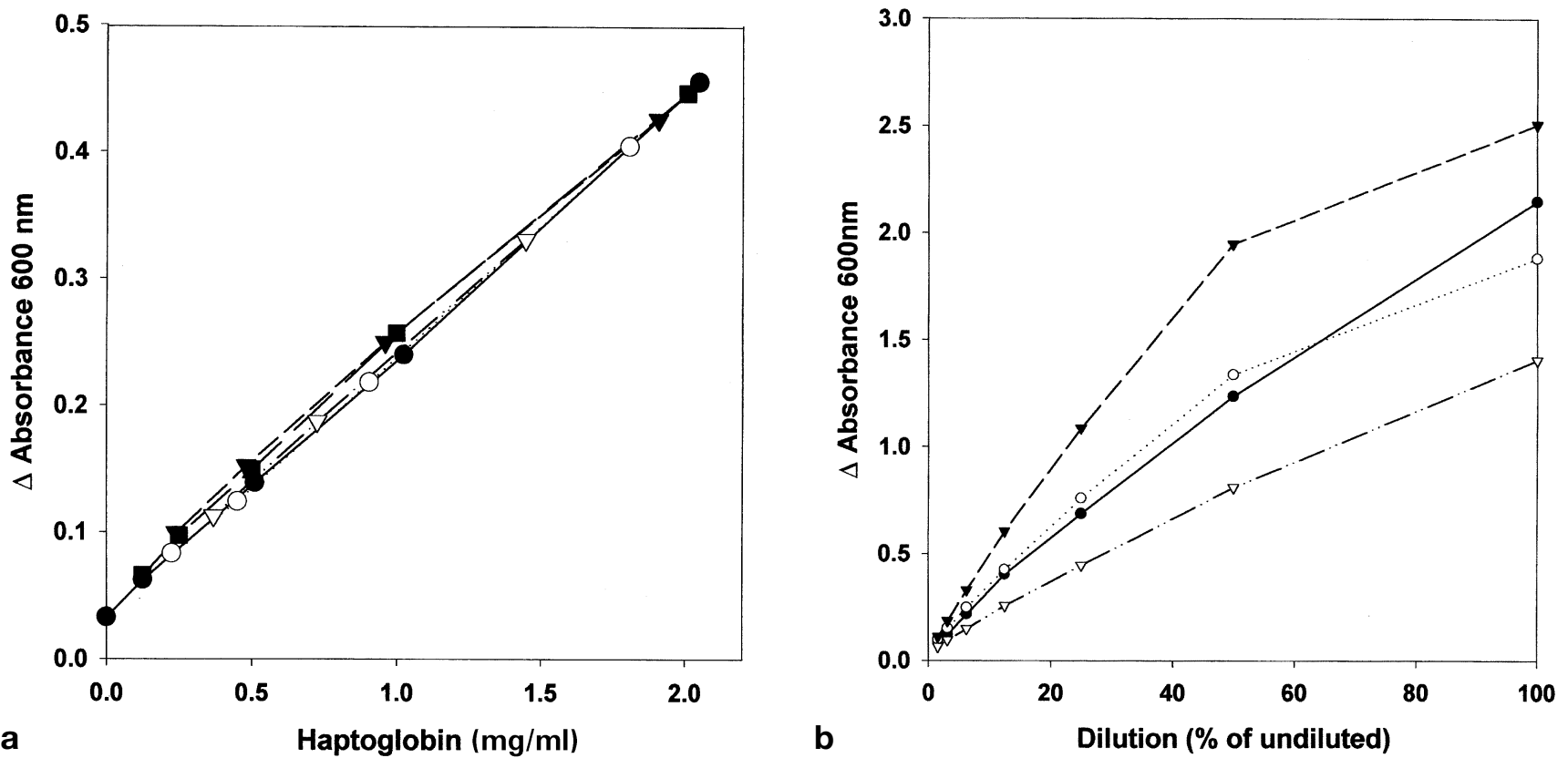

Fig. 3. (a) Dilution of sera sample with a high concentrations of $\mathrm{Hp}(\mathbf{O}), \mathbf{\square}, \boldsymbol{\nabla}, \nabla)$ and $0.13 \mathrm{mg} / \mathrm{ml}(\nabla)$ in 9 , with fetal calf serum compared with the Hp standard curve in the assay using reagent SB-7 (O). (b) Serial dilution, as percentage of undiluted, of sera with $\mathrm{Hp}$ at $22.5 \mathrm{mg} / \mathrm{ml}$ $(--), 14.6 \mathrm{mg} / \mathrm{ml}(-), 14.5 \mathrm{mg} / \mathrm{ml}(\cdots)$ and $8.7 \mathrm{mg} / \mathrm{ml}(-\cdots)$ against the change in absorbance at $600 \mathrm{~nm}$ to show linearity of the Hp assay.

Table 3. Precision of SB-7 Hp assay

\begin{tabular}{llll}
\hline Intra-assay CV $(n=10)$ & & & \\
Mean Hp concentration $(\mathrm{mg} / \mathrm{ml})$ & 2.04 & 0.97 & 0.23 \\
Standard deviation & 0.018 & 0.009 & 0.003 \\
Coefficient of variance (\%) & 0.88 & 0.93 & 1.30 \\
Inter-assay CV $(n=12)$ & & & \\
Mean Hp concentration $(\mathrm{mg} / \mathrm{ml})$ & 2.08 & 0.24 & \\
Standard deviation & 0.035 & 0.011 & \\
Coefficient of variance $(\%)$ & 1.68 & 4.50 & \\
& &
\end{tabular}

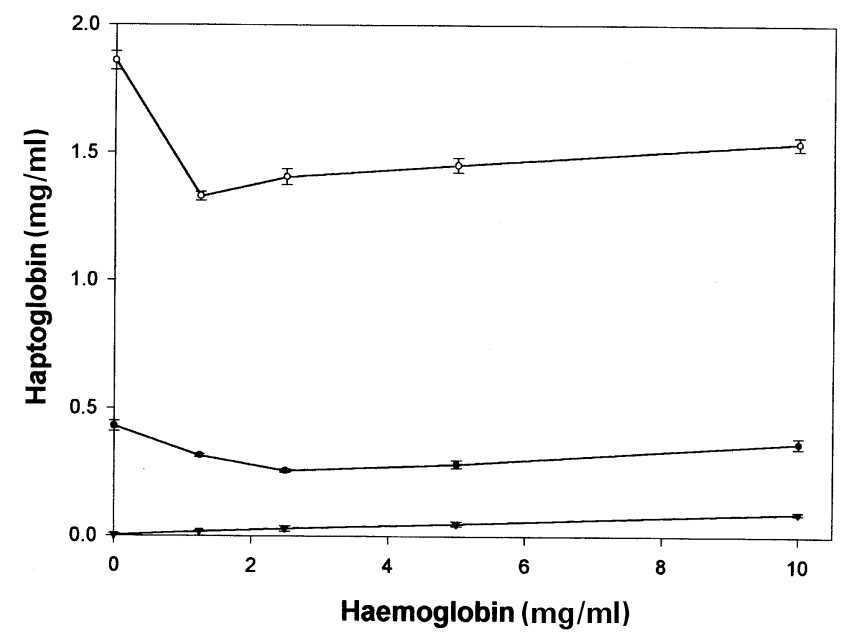

Fig. 4. Interferogram showing the effect of increasing concentrations of haemoglobin added to samples of serum on the apparent $\mathrm{Hp}$ concentration. Serum samples had Hp concentrations of $0.02 \mathrm{mg} / \mathrm{ml}$ $(\nabla), 0.41 \mathrm{mg} / \mathrm{ml}(\bullet)$, or $1.8 \mathrm{mg} / \mathrm{ml}(\bigcirc)$.
The presence of increasing amounts of haemoglobin in the sample had a moderate effect on the Hp assay in samples with a low concentration of $\mathrm{Hp}$, over a haemoglobin range of $0.3-10 \mathrm{mg} / \mathrm{ml}$ (Fig. 4). At a greater Hp concentrations a drop in Hp was observed followed by a gradual rise as the haemoglobin concentration reached $10 \mathrm{mg} / \mathrm{ml}$. Lipaemia and bilirubinaemia had no effect on the Hp concentration (data not shown).

Increasing concentrations of heparin in plasma caused increases in the apparent $\mathrm{Hp}$ concentration. At 10 and $20 \mathrm{IU} / \mathrm{ml}$ of heparin an elevation of $0.04 \mathrm{mg} / \mathrm{ml}$ in the apparent $\mathrm{Hp}$ concentration was obtained whereas at $40 \mathrm{IU} / \mathrm{ml}$ this increased to $0.07 \mathrm{mg} / \mathrm{ml}$ (data not shown).

\section{Comparison with Immunodiffusion}

There was a highly significant correlation between the $\mathrm{Hp}$ concentrations determined in bovine serum samples by the SB-7 $\mathrm{Hp}$ assay and by the immunodiffusion method (Fig. 5a) with a correlation coefficient $\left(R^{2}\right)$ of $0.96(p<0.001)$ and a regression equation of $\mathrm{Hp}_{\text {imm }}=$ $0.01+0.40 \mathrm{Hp}_{\mathrm{SB} 7}$. There was a highly significant correlation between the Hp concentrations determined in canine plasma samples by the SB-7 Hp assay and by the immunodiffusion method (Fig.5b) with a correlation coefficient $\left(R^{2}\right)$ of $0.90(p<0.001)$ and a regression equation of $\mathrm{Hp}_{\mathrm{imm}}=0.74+0.47 \mathrm{Hp}_{\mathrm{SB} 7}$. 


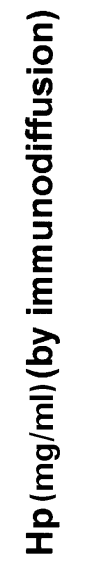

a

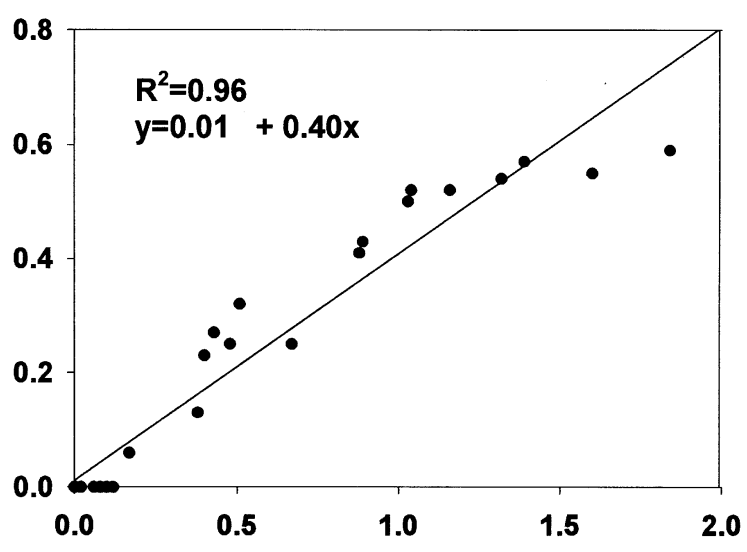

Haptoglobin (mg/ml)(by SB-7)

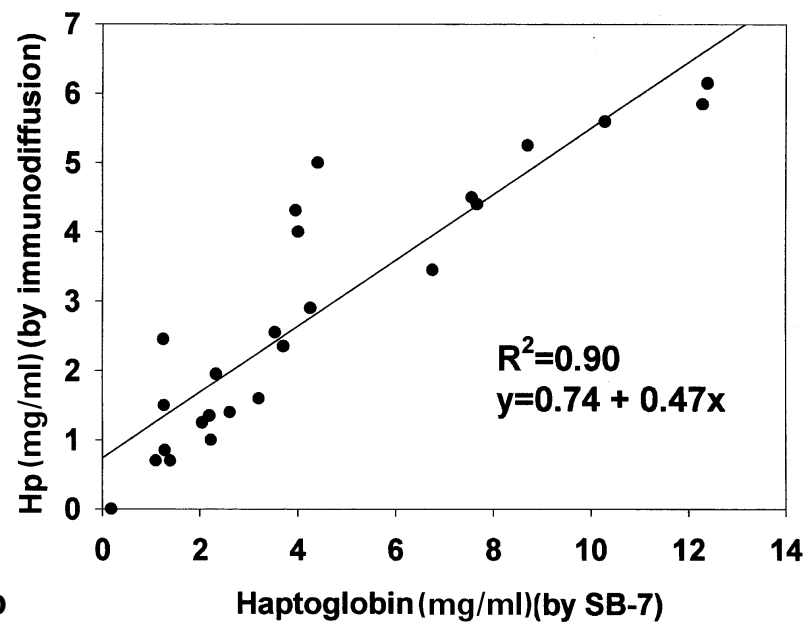

b

Fig. 5. Comparison of the results of the Hp assay to those obtained by immunodiffusion with (a) bovine and (b) canine serum samples.

Table 4. Serum haptoglobin concentration in serum from dairy cows with mastitis and in normal uninfected dairy cows

\begin{tabular}{lll}
\hline & $\begin{array}{l}\text { Dairy cows } \\
\text { with mastitis }\end{array}$ & $\begin{array}{l}\text { Uninfected } \\
\text { dairy cows }\end{array}$ \\
\hline Mean Hp concentration $(\mathrm{mg} / \mathrm{ml})$ & 1.26 & $\mathrm{n} / \mathrm{a}^{\mathrm{a}}$ \\
Standard deviation & 0.66 & $\mathrm{n} / \mathrm{a}^{\mathrm{a}}$ \\
Range of Hp $(\mathrm{mg} / \mathrm{ml})$ & $0.02-2.80$ & $0.02-0.10^{\mathrm{a}}$ \\
Number of samples & 18 & 23 \\
Median $(\mathrm{mg} / \mathrm{ml})$ & 1.24 & $<0.02$ \\
\hline
\end{tabular}

${ }^{a}$ Only 4 of 23 samples had a detectable concentration of Hp.

Table 5. Haptoglobin concentration in plasma from dogs with polyarthritis and from healthy dogs

\begin{tabular}{llc}
\hline & $\begin{array}{l}\text { Dogs with } \\
\text { polyarthritis }\end{array}$ & $\begin{array}{l}\text { Healthy } \\
\text { dogs }\end{array}$ \\
\hline Mean Hp concentration $(\mathrm{mg} / \mathrm{ml})$ & 11.6 & 0.60 \\
Standard deviation & 3.2 & 0.55 \\
Range of Hp (mg/ml) & $7.2-16.5$ & $0-1.69$ \\
Number of samples & 8 & 27 \\
Median $(\mathrm{mg} / \mathrm{ml})$ & 11.3 & 0.44 \\
\hline
\end{tabular}

\section{Applications of the SB-7 Hp Assay}

Cattle. The mean \pm SD serum Hp concentration in dairy cows with mastitis was $1.26 \pm 0.66 \mathrm{mg} / \mathrm{ml}$ with a range of $0.02-2.80 \mathrm{mg} / \mathrm{ml}$ (Table 4). Serum from cows without clinical signs of disease had undetectable concentrations of serum $\mathrm{Hp}(n=19)$ or had a low concentration of $<0.10 \mathrm{mg} / \mathrm{ml}(n=4)$.

Dogs. The mean $( \pm$ SD) Hp concentration in plasma from dogs with polyarthritis, after correction for the heparin effect on the $\mathrm{Hp}$ assay, was $11.6 \pm 3.2 \mathrm{mg} / \mathrm{ml}$ with a range of $7.2-16.5 \mathrm{mg} / \mathrm{ml}$ (Table 5). In healthy

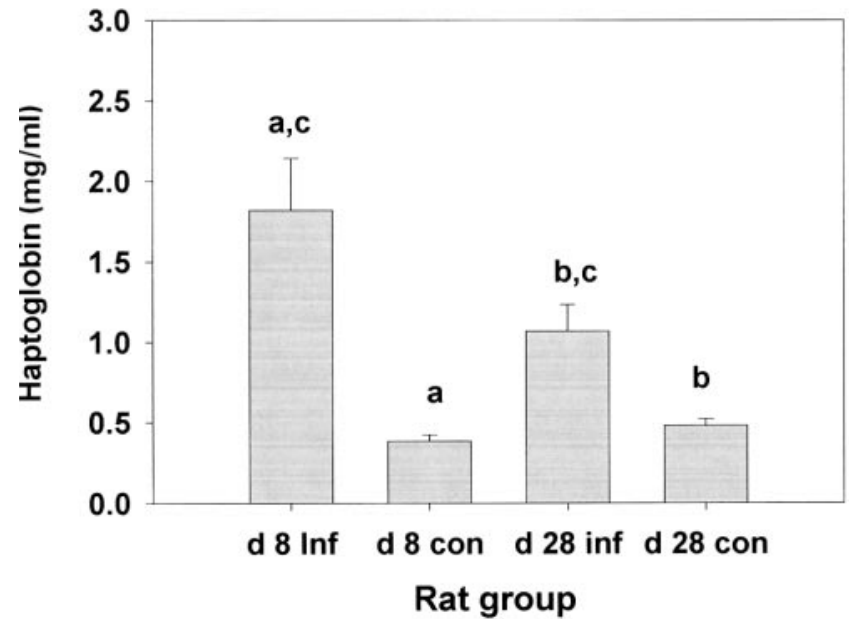

Fig. 6. The mean concentration $( \pm$ SEM $)$ of $\mathrm{Hp}$ in serum from experimental rats infected intrabronchially with B. pertussis at 8 or 28 days postinfection compared with the Hp concentration in control, uninfected animals ( $n=8$ in all groups); a, b: significant difference $(p<0.01)$ between infected and control animals on the same day; c, significant difference $(p<0.05)$ between infected animals on day 8 and day 28 .

dogs the plasma $\mathrm{Hp}$ concentration had a mean of $0.60 \pm$ $0.55 \mathrm{mg} / \mathrm{ml}$ and a range of $0-1.69 \mathrm{mg} / \mathrm{ml}$. Hp in samples from dogs with polyarthritis were significantly higher than in normal animals with $p<0.001$.

Rats. The mean plasma serum Hp concentration in rats 8 days after infection with $B$. pertussis was $1.82 \pm 0.79$ $\mathrm{mg} / \mathrm{ml}$ (Fig. 6) which was significantly greater $(p<0.01)$ than the mean $\mathrm{Hp}$ concentration in uninfected control rats $(0.39 \pm 0.10 \mathrm{mg} / \mathrm{ml})$. After 28 days the mean $\mathrm{Hp}$ in infected rats had fallen to $1.07 \pm 0.44 \mathrm{mg} / \mathrm{ml}$ which was still significantly greater $(p<0.01)$ than the mean of uninfected control rats $(0.48 \pm 0.01 \mathrm{mg} / \mathrm{ml})$ sampled on the 28th day after treatment. There was a significant difference between the infected animals on day 8 and day $28(p<0.05)$. 


\section{Discussion}

During initial attempts to develop automated assays for serum Hp, commonly used reagents such as TMB or ABTS were assessed for use as peroxidase chromogen. However, automated methods using these substrates had a consistent problem in estimating zero control samples. With TMB as chromogen, BSA, which did not contain peroxidase activity in the absence of $\mathrm{Hb}$, gave apparent $\mathrm{Hp}$ concentrations of up to $0.16 \mathrm{mg} / \mathrm{ml}$ and ABTS gave apparent $\mathrm{Hp}$ concentrations of up to 0.28 $\mathrm{mg} / \mathrm{ml}$. There was a residual peroxidase activity even with the BSA samples assayed with SB-7 reagent, but this was low enough to cause negligible interference with clinical interpretation of assay results, especially with $2 \%$ BSA being used as the diluent for standards. This results in the residual interference from 5\% BSA being $0.01 \mathrm{mg} / \mathrm{ml}$, which is within the assay limit of detection $(0.02 \mathrm{mg} / \mathrm{ml})$ based on the repeatability of the zero standard. Nevertheless, further modification may be possible to eliminate the albumin interference completely.

It is possible that the low peroxidase activity associated with albumin is a result of its ability to bind haematin as albumin-haematin complexes which are known to retain peroxidase activity (Benesch and Kwong 1990; Gattoni et al. 1996). In species such as humans, dogs and pigs where the concentration of $\mathrm{Hp}$ in healthy animals is not negligible a small albumin effect may be unimportant for monitoring inflammation, but $\mathrm{Hp}$ can also be used to monitor conditions such as haemolytic anaemia when the concentration falls and albumin interference would be significant. However, for species where $\mathrm{Hp}$ is in the order of $<0.01 \mathrm{mg} / \mathrm{ml}$ in healthy animals it is essential to minimise this interference.

Having identified albumin as the cause interference of the Hp assay, a screen of potential agents to eliminate the interference led to the development of the chromogen reagent SB-7 which proved to be amenable for use in the automated assay system (Fig. 1). The interference of albumin with the Hp assay is likely to have been overlooked in previous assays either by the sample dilutions required for assays based on sensitive chromogens such as TMB (Eckersall et al. 1988) or by the use of less insensitive chromogens such as guaiacol (Skinner et al. 1991) which, due to its odour is not acceptable in many diagnostic laboratories. An additional benefit of SB-7 over TMB as a chromogen is that the end product colour of the oxidised SB-7 is stable at the assay $\mathrm{pH}$, whereas TMB was found to be unstable and could only be used with all samples being diluted 1:10.

Validation studies on this novel $\mathrm{Hp}$ assay revealed acceptable levels of precision in intra- and interassay CVs. The dilution studies indicated that diluted clinical samples gave acceptable parallel dilution curves to the standard curve. The interferogram (Fig. 4) showed that at a low level of $\mathrm{Hp}$ there was little interference from $\mathrm{Hb}$, whereas at higher levels of $\mathrm{Hp}, \mathrm{Hb}$ caused a fall in the observed Hp result. Understanding the shape of this interferogram requires further study, but it is apparent that haemolysis could cause a slight decrease in reported values at such levels of Hp. However, this is not likely to greatly affect the interpretation of the result, although it would be advisable to avoid grossly haemolysed samples. It was notable that neither lipaemia nor bilirubinaemia interfered with the Hp assay. The finding that heparin caused a slight increase in apparent $\mathrm{Hp}$ concentration means that the assay is best used on serum or plasma with alternative anticoagulants such as EDTA, but as the effect is small, heparin plasma can be used if results are suitably adjusted. The linearity study, showing that results could be extrapolated up to $8 \mathrm{mg} /$ $\mathrm{ml}$, was further evidence of the usability of the assay such that judicious alteration of sample volume and standardisation should allow the assay to be performed without dilution up to $\mathrm{Hp}$ concentrations at this higher level.

Comparison with immunodiffusion of bovine serum and canine plasma revealed significant correlation confirming that the assay is measuring $\mathrm{Hp}$ in both species. The gradients of the regression equation were not unity due to differences in the calibrant used here and in the immunodiffusion kits. Suitable international reference preparations of animal serum proteins are not available and as a result, laboratories around the world have prepared their own standard material. An initiative has been suggested to remedy this deficiency of international comparative clinical pathology laboratories (Eckersall et al. 1999). Unfortunately canine serum was not available for this study but the effect of heparin as anticoagulant would not alter the correlation or the clinical findings on cases discussed below.

The application of the Hp assay was demonstrated in preliminary investigation in three species of animals. Dairy cattle with acute mastitis have elevated levels of Hp consistent with the inflammatory nature of this condition, with the $\mathrm{Hp}$ concentration increasing from negligible to greater than $2.5 \mathrm{mg} / \mathrm{ml}$ in some cases. Hp could be used as an indicator for mastitis and particularly for mastitis in the dry cow, when milk samples are not available for somatic cell counting. Dogs with polyarthritis had up to a ten-fold elevation of $\mathrm{Hp}$ and the assay is likely to be useful in diagnosis and monitoring of this and other inflammatory conditions. SpragueDawley rats with experimental $B$. pertussis infection showed a fourfold increase in serum Hp at day 8 after infection, demonstrating that this convenient assay could be of significant value in laboratory animal clinical biochemistry to monitor the progress of the acute phase reaction in studies of inflammation and infection. As this assay is now available in kit form, it can be applied to all species and could even supplement investigation of inflammatory markers in humans where $\mathrm{Hp}$ is a moderate acute phase protein in contrast to the rapid responses seen with $\mathrm{C}$-reactive protein.

Acknowledgements. The authors would like to thank the Biotechnology and Biological Sciences Research Council (SD), the Wellcome 
Trust (PDE and NUH), The Royal Society (SS), Scottish Hospital Endowment Research Trust (RP), Pet Plan Ltd, (SD) and the Milk Development Council (JLF) for support during the work leading to this publication.

\section{References}

Benesch RE, Kwong S (1990) The stability of the heme-globin linkage in some normal, mutant and chemically modified hemoglobins. J Biol Chem 266:14881-14885

Eckersall PD (1995) Acute phase proteins as markers of inflammatory lesions. Comp Haematol Int 5:93-97

Eckersall PD, Conner JG (1988) Bovine and canine acute phase proteins. Vet Res Comm 12:169-178

Eckersall PD, Parton H, Conner JG et al. (1988) Acute phase reactants in diseases of $\operatorname{dog}$ and cattle. In: Blackmore DJ, Eckersall PD, Evans GO et al. (eds) Animal clinical biochemistry: the future. Cambridge University Press, Cambridge, pp 225-230

Eckersall PD, Duthie S, Toussaint MJM et al. (1999) Standardization of diagnostic assays for animal acute phase protein. Ad Vet Med 41:643-655

Eurell TE, Bane DP, Hall WF et al. (1992) Serum haptoglobin concentration as an indicator of weight-gain in pigs. Can J Vet Res 56:6-9

Gattoni M, Boffi A, Sarti P et al. (1996) Stability of the heme-globin linkage in ab dimers and isolated chains of human hemoglobin. $\mathrm{J}$ Biol Chem 271:10130-10136

Hall E, Parton R, Wardlaw AC (1994) Cough production, leucocytosis and serology of rats infected intrabronchially with Bordetella pertussis. J Med Microbiol 40:205-213

Harvey JW (1986) Comparison between serum haptoglobin and alpha-2-globulin concentrations in dogs. Vet Clin Pathol 15:4-5

Horadagoda A, Eckersall PD, Hodgson JC et al. (1994) Immediate responses in serum TNFa and acute phase protein concentrations to infection with Pasteurella haemolytica A1 in calves. Res Vet Sci 57:129-132

Kushner I, Mackiewicz A (1987) Acute phase proteins as disease markers. Dis Marker 5:1-11

Lipperheide C, Diepers N, Lampreave F et al. (1998) Nephelometric determination of haptoglobin plasma concentrations in fattening pigs. J Vet Med A 45:543-550

Makimura S, Suzuki N (1982) Quantitative determination of bovine serum haptoglobin and its elevation in some inflammatory diseases. Jap J Vet Sci 44:15-21

Schmitt U, Deeg R, Ziegenhorn J (1987) Process and reagents for the determination of the heamoglobin-haptoglobin complex in the presence of free heamoglobin. US Patent no 4,695,552

Skinner JG, Roberts L (1994) Haptoglobin as an indicator of infection in sheep. Vet Rec 134:33-36 (Abstract)

Skinner JG, Brown RAL, Roberts L (1991) Bovine haptoglobin response in clinically defined field conditions. Vet Rec 128:147149

Solter PF, Hoffmann WE, Hungerford LL et al. (1991) Haptoglobin and ceruloplasmin as determinants of inflammation in dogs. Am J Vet Res 52:1738-1742

Whicher JT, Westacott CI (1992) The acute phase response. In: Whicher JT, Evans SW (eds) Biochemistry of inflammation. Kluwer Academic, London, pp 243-271 